\title{
Deuterium excess in the atmospheric water vapour of a Mediterranean coastal wetland: regional vs. local signatures
}

\author{
H. Delattre, C. Vallet-Coulomb, and C. Sonzogni \\ Aix-Marseille Université, CNRS, IRD, CEREGE UM34, Europôle méditerranéen de l'Arbois, \\ 13545 Aix-en-Provence, France \\ Correspondence to: C. Vallet-Coulomb (vallet@ cerege.fr)
}

Received: 20 December 2014 - Published in Atmos. Chem. Phys. Discuss.: 20 January 2015

Revised: 17 August 2015 - Accepted: 30 August 2015 - Published: 14 September 2015

\begin{abstract}
Stable isotopes of water vapour represent a powerful tool for tracing atmospheric vapour origin and mixing processes. Laser spectrometry recently allowed high timeresolution measurements, but despite an increasing number of experimental studies, there is still a need for a better understanding of the isotopic signal variability at different time scales. We present results of in situ measurements of $\delta^{18} \mathrm{O}$ and $\delta \mathrm{D}$ during 36 consecutive days in summer 2011 in atmospheric vapour of a Mediterranean coastal wetland exposed to high evaporation (Camargue, Rhône River delta, France). The mean composition of atmospheric vapour $\left(\delta_{v}\right)$ is $\delta^{18} \mathrm{O}=-14.66 \%$ and $\delta \mathrm{D}=-95.4 \%$, with data plotting clearly above the local meteoric water line on a $\delta^{18} \mathrm{O}-\delta \mathrm{D}$ plot, and an average deuterium excess $(d)$ of $21.9 \%$ o. Important diurnal $d$ variations are observed, and an hourly time scale analysis is necessary to interpret the main processes involved in its variability. After having classified the data according to air mass back trajectories, we analyse the average daily cycles relating to the two main meteorological situations, i.e. air masses originating from North Atlantic Ocean and Mediterranean Sea. In both situations, we show that diurnal fluctuations are driven by (1) the influence of local evaporation, culminating during daytime, and leading to an increase in absolute water vapour concentration associated to a $\delta_{\mathrm{v}}$ enrichment and $d$ increase; (2) vertical air mass redistribution when the Planetary Boundary Layer collapses in the evening, leading to a $d$ decrease, and (3) dew formation during the night, producing a $\delta_{\mathrm{v}}$ depletion with $d$ remaining stable. Using a twocomponent mixing model, we calculate the average composition of the locally evaporated vapour $\left(\delta_{\mathrm{E}}\right)$. We find higher $d_{(\mathrm{E})}$ under North Atlantic air mass conditions, which is consistent with lower humidity conditions. We also suggest that $\delta_{\mathrm{v}}$ mea-
\end{abstract}

sured when the PBL collapses is the most representative of a regional signal. Strong, cold and dry winds coming from the north bring an isotopically depleted vapour, while light, warm and wet winds coming from the south bring an isotopically enriched vapour. Under northern conditions, a strong advection rate dilutes the contribution of the locally evaporated vapour $\left(\delta_{\mathrm{E}}\right)$ to the ambient moisture $\left(\delta_{\mathrm{V}}\right)$. The higher $d$ values measured under northern conditions, compared to the Mediterranean situation, thus results from the combination of a higher $d$ in both local and regional vapour. This depiction of typical daily cycles of water vapour isotopic composition can be used as a framework for further quantitative analyses of vapour sources during specific days.

\section{Introduction}

At the global scale, an acceleration of the hydrological cycle is expected in response to climate change, with an intensification of both precipitation and evaporation. This effect has been recognized for the ocean (Dai et al., 2009), but less conclusive patterns appear for continental surfaces, especially because of the complex behaviour of land evapotranspiration (Ohmura and Wild, 2002; Roderick and Farquhar, 2002; Brutsaert, 2006; Roderick et al., 2007; Fu et al., 2009; Jung et al., 2010). The response of evapotranspiration to climate change is controlled both by climatic and by hydrological parameters. Climate determines the atmospheric evaporative demand (potential evapotranspiration), while hydrology controls surface water availability, thus limiting actual evapotranspiration. In addition, continental vapour is involved in land-atmosphere feedbacks such as atmospheric 
water recycling; high evapotranspiration may contribute to regional rainfall in contexts of tropical rainforest (Brubaker et al., 1993; Eltahir and Bras, 1996; van der Ent et al., 2010) or large scale irrigation (Boucher et al., 2004; Tuinenburg et al., 2012), or may even reduce potential evapotranspiration by lowering temperature and increasing humidities near the earth surface (Destouni et al., 2010; Tuinenburg et al., 2012). A better understanding of the atmospheric component of the water cycle and of the potential contribution of wetlands evaporation to the regional water budget is thus important to anticipate the impact of global change, in particular in Mediterranean regions where more frequent droughts are expected.

Isotopic composition of atmospheric water vapour (subsequently called $\delta_{\mathrm{v}}$ ) represents a great opportunity to explore land-atmosphere interactions, as the addition of moisture originating from evapotranspiration induces a modification of the isotopic content of the background vapour (Salati et al., 1979; Gat and Matsui, 1991; Gat et al., 1994; Gat, 2000; Worden et al., 2007; Yamanaka and Shimizu, 2007; Vallet-Coulomb et al., 2008; Risi et al., 2013). In addition, isotope tracers are now often incorporated into climate models (Sturm et al., 2005; Werner et al., 2011; Risi et al., 2012,2013 ) in order to improve the representation of landatmosphere interactions and feedbacks. A major challenge is thus to propose robust databases, and associated methodology for data acquisition and interpretation.

Laser spectrometers recently opened the door towards the high temporal resolution analysis of $\delta_{\mathrm{v}}$ variations, which was not possible with the traditional cold trap method. Whereas cryogenic trapping provides grab samples generally averaging a couple of hours, laser spectrometry performs continuous high frequency (up to $\sim 1 \mathrm{~Hz}$ ) measurements of $\delta_{\mathrm{V}}$ (Kerstel and Gianfrani, 2008). This technology offers new insights into processes that affect the isotopic composition of atmospheric water vapour and the number of studies based on continuous ground level isotope measurements over multiweek periods is continuously increasing, either using a tunable diode laser (TDL) (Lee et al., 2006; Wen et al., 2010, 2012; Griffis et al., 2011; Welp et al., 2012), off-axis integrated cavity output spectroscopy (OA-ICOS) (Sturm and Knohl, 2010; Sunmonu et al., 2012; Farlin et al., 2013; SteenLarsen et al., 2013) or wavelength-scanned cavity ring-down spectroscopy (WS-CRDS) (Galewsky et al., 2011; Noone et al., 2011; Tremoy et al., 2012; Steen-Larsen et al., 2013, 2014). Among these experiments are some low latitude studies which have focused on the tracing of tropical or subtropical convective activity in West Africa (Tremoy et al., 2012) or in South America (Galewsky et al., 2011). In mid latitudes (Noone et al., 2011; Farlin et al., 2013), or high latitudes (Steen-Larsen et al., 2013), several studies have explored atmospheric mixing processes at different time scales. Isotopes have also been used for partitioning evapotranspiration into plant transpiration and direct evaporation, as the associated fractionations are different (Yakir and Sternberg,
2000; Lai et al., 2006; Wang et al., 2010; Griffis et al., 2011; Sun et al., 2014), for a better understanding of the role of ecosystems in the hydrological cycle in the context of climate change (Wang et al., 2013).

However, the number of studies remains limited because of technical difficulties associated with field-deployed longterm measurements. Except for some work based on cold trap sampling (Jacob and Sonntag, 1991; Williams et al., 2004; Angert et al., 2008), there are to our knowledge only three high time-resolution studies published from European sites (Iannone et al., 2010; Kurita et al., 2012; Aemisegger et al., 2014) and none at all treating Mediterranean areas. In addition, there is a need for dual tracer databases, in order to use the deuterium excess signal $\left(d=\delta \mathrm{D}-8 \times \delta^{18} \mathrm{O}\right.$; Dansgaard, 1964) as an additional indicator of atmospheric processes. Indeed, $d$ is often considered as a indicator of evaporation conditions, but its interpretation in continental vapour remains complex since it is affected by the multiple vapour sources, combining the initial oceanic vapour and evapotranspiration from different continental water sources (Gat et Matsui, 1991; Vallet-Coulomb et al., 2008; Lai and Ehleringer, 2011; Welp et al., 2012; Jouzel et al., 2013; Aemisseger et al., 2014).

In this paper, we provide results obtained in Camargue on 36 consecutive days during summer 2011, using WS-CRDS technology. The Camargue region is emblematic of Mediterranean wetlands, with important water inflow requirements and strong evaporation losses, making it highly sensitive to climate change and human pressure on water resources. Our experimental site is located in the centre of Camargue, close to the main lagoon (Vaccarès lagoon, $65 \mathrm{~km}^{2}$ ). Considering the location of the site, and the important availability of open water in the surroundings, we expect a dominant contribution of evaporation upon transpiration fluxes. This study will provide the opportunity to investigate how local evaporation combines and interact with the other regional vapour sources. We will focus on identifying the main drivers of deuterium excess variability at different time scales, and explore the relevance of using either relative humidity, as an indicator of evaporation conditions, or specific humidity (mixing ratio) as a proxy of mixing between different vapour sources. Before analysing our results, we present technical aspects of measurement calibration and validation. We then analyse the day-to-day variations of $\delta_{\mathrm{v}}$ and $d$ in relation to climatic parameters and the air mass back trajectories. Finally, average hourly variations are explored and we interpret the typical daily cycles according to the main regional meteorological conditions in order to depict their driving factors and the influence of local processes. 


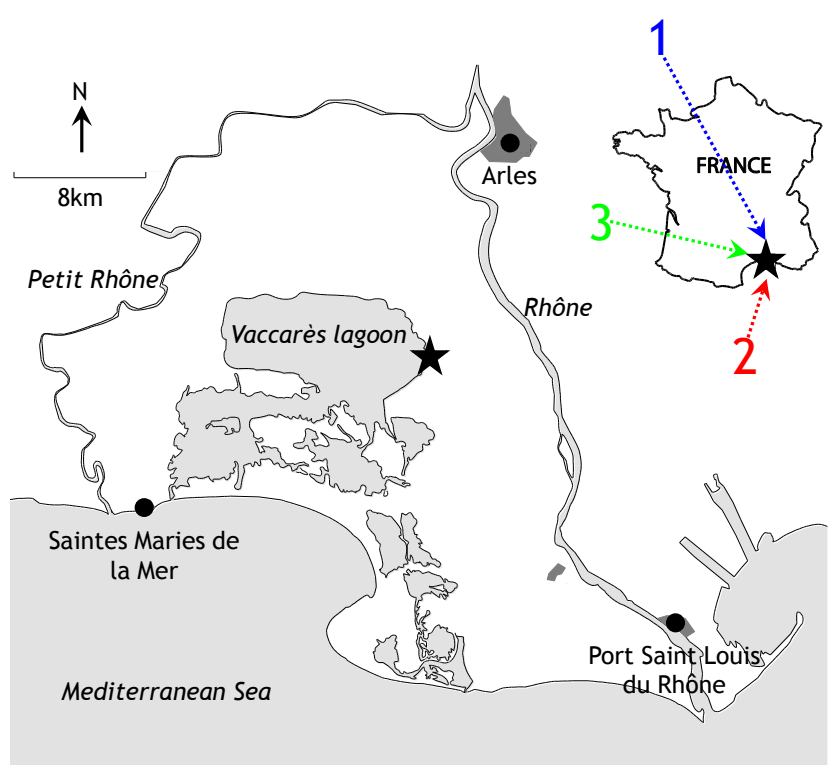

Figure 1. Location of the experimental site (star) in Camargue (Rhône River delta), $170 \mathrm{~m}$ from the Vaccarès lagoon and $12 \mathrm{~km}$ from the Mediterranean Sea. Coloured arrows represent the three main origins and trajectories of air masses affecting the study site, (1) North Atlantic, (2) Mediterranean and (3) Bay of Biscay.

\section{Data acquisition}

\subsection{Protocols}

Continuous in situ measurements of the isotopic composition of atmospheric water vapour $\left(\delta^{18} \mathrm{O}\right.$ and $\left.\delta \mathrm{D}\right)$ were performed during summer 2011 between 20 July and 24 August, at $1.75 \mathrm{~m}$ height and approximately $170 \mathrm{~m}$ from the eastern border of the Vaccarès lagoon (Fig. 1), using WavelengthScanned Cavity Ring-Down Spectroscopy (WS-CRDS). The instrument we use is the Picarro L1102-i isotopic liquid water and water vapour analyser (Picarro Inc., Sunnyvale, California, USA), which measures the isotopic composition of atmospheric water vapour every 5 to $7 \mathrm{~s}$. Installed in an airconditioned room, the analyser is connected to an outside air intake. As water vapour may be sticky on the walls of any tubing, a bypass configuration is used to bring the air in quickly, at a rate of $6 \mathrm{~L} \mathrm{~min}^{-1}$ (with a Laboport vacuum pump N86 KN.18) through PVC tubing, in order to minimise wall effects that lead to fractionation in the inlet. The analyser then subsamples this air at a rate lower than $0.04 \mathrm{Lmin}^{-1}$.

Calibration of laser measurements is performed according to liquid laboratory standards, and a three-way valve allows switching between the introduction of ambient air and vapour from the liquid sample vaporizer (vaporization module V1102-i adjusted to $110^{\circ} \mathrm{C}$ for flash vaporization to avoid fractionation). We used three laboratory standards whose isotopic compositions span a range of values including the com-
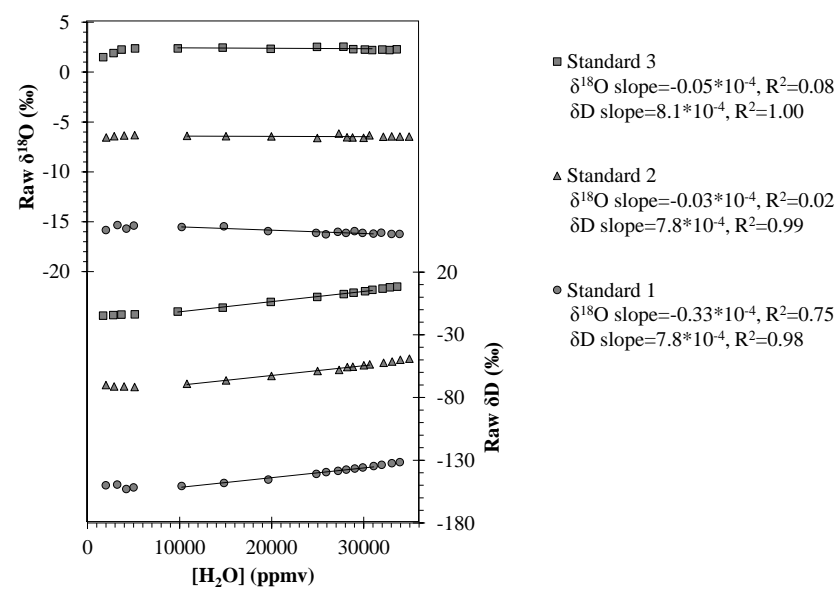

Figure 2. Raw $\delta^{18} \mathrm{O}$ and $\delta \mathrm{D}$ of our three laboratory liquid standards measured at various water vapour concentrations. Error bars are smaller than the symbols. Linear regressions within the concentration range encountered in Camargue during the field experiment and associated slopes and determination coefficients are shown.

position expected in the atmosphere of the Camargue (Table 1). $1.8 \mu \mathrm{L}$ of water standards is injected into the vaporizer using an autosampler (CTC Analytics LEAP Technologies HTC PAL autosampler) with a SGE $5 \mu \mathrm{L}$ syringe. We used synthetic air as the dry carrier gas (water content $<45 \mathrm{ppmv}$ ) delivered at a pressure of $2.5 \pm 0.5 \mathrm{psi}$. The analyser takes about $9 \mathrm{~min}$ to perform approximately 40 measurements per injection, and these results are then averaged by the software. Between each injection, the syringe is cleaned with 1methyl-2-pyrrolidinone (NMP) solvent wash. Our laboratory successfully participated in the IAEA 2011 proficiency test on routine analysis of $\delta^{18} \mathrm{O}$ and $\delta \mathrm{D}$ in liquid water (Wassenaar et al., 2012).

Previous studies have shown that optical spectrometric methods can induce a dependence of isotopic measurements on water vapour concentration (Gupta et al., 2009; Schmidt et al., 2010; Johnson et al., 2011; Tremoy et al., 2011). This does not affect liquid sample measurements, since the water quantity introduced into the analyser through the vaporizer is nearly constant, but important variations of vapour content do occur when analysing ambient atmosphere, making it necessary to correct optical measurements. We have evaluated the concentration dependence of our instrument for a large range of water concentrations, and for different isotopic compositions using our three standards (Fig. 2). In addition, for routine analyses, an evaluation of the water concentration effect is performed at intervals of approximately $24 \mathrm{~h}$ with the more depleted standard (standard 1) whose isotopic composition is close to the atmosphere of the $\mathrm{Ca}$ margue. The autosampler is set to perform six injections of $0.9,1.6$ and $2.0 \mu \mathrm{L}$ in the vaporization module to obtain three water vapour concentrations ranging from about 8000 to $28000 \mathrm{ppmv}$, comprising values expected in the study 
Table 1. Isotopic compositions of laboratory standards $\left(\delta_{\mathrm{LS}}\right)$, and statistics on raw measurements from all calibrations (average and standard deviation of $\delta_{\text {raw }}$ from 40 data between 20 July to $24 \mathrm{Au}-$ gust 2011).

\begin{tabular}{|c|c|c|c|c|}
\hline & & $\begin{array}{l}\delta_{\mathrm{LS}}(\% \circ \mathrm{vs} . \\
\text { VSMOW) }\end{array}$ & $\begin{array}{l}\text { Average } \\
\text { deviatio }\end{array}$ & $\begin{array}{l}\text { standard } \\
\text { raw }(\% o)\end{array}$ \\
\hline \multirow{2}{*}{ Standard 1} & $\delta^{18} \mathrm{O}$ & -17.12 & -13.89 & 0.19 \\
\hline & $\delta \mathrm{D}$ & -133.3 & -152.6 & 2.0 \\
\hline \multirow{2}{*}{ Standard 2} & $\delta^{18} \mathrm{O}$ & -7.85 & -4.85 & 0.11 \\
\hline & $\delta \mathrm{D}$ & -53.5 & -71.1 & 1.5 \\
\hline \multirow{2}{*}{ Standard 3} & $\delta^{18} \mathrm{O}$ & 0.68 & 3.41 & 0.08 \\
\hline & $\delta \mathrm{D}$ & 3.7 & -12.8 & 1.8 \\
\hline
\end{tabular}

area. In addition, calibration for isotopic composition is performed at least every $24 \mathrm{~h}$ with our three standards. For each standard, the autosampler is set to perform six injections of $1.8 \mu \mathrm{L}$ in the vaporization module, corresponding to a water vapour concentration of approximately $20000 \mathrm{ppmv}$. The first two injections are disregarded to remove the memory effect, and the last four injections are averaged to obtain the $\delta^{18} \mathrm{O}$ and $\delta \mathrm{D}$ measurements of each standard.

Gaps in time series correspond to calibration periods, but may also reflect accidental power cuts or data eliminated during episodes of condensation in the tubing. This latter problem was detected thanks to the use of transparent air tubing, and was easily recognizable a posteriori through the abnormally smooth shape of the water vapour concentration curve. A heating cable was then used to avoid any condensation such as may occur when a negative temperature gradient exists between the sampling point and the inlet of the analyser.

\subsection{Dependence on water vapour concentration}

It has been shown that the dependence of WS-CRDS isotopic measurements on water vapour concentration is specific to the individual analyser (e.g. Johnson et al., 2011; Tremoy et al., 2011; Aemisegger et al., 2012). The concentration dependence of our instrument, evaluated for a large range of concentrations (Fig. 2), showed a linear response in the range of water vapour concentration measured in the atmosphere of the Camargue (from 9000 to $28000 \mathrm{ppmv}$ ), with the relationship deviating slightly from the linear trend at very low and high water vapour concentrations. For $\delta^{18} \mathrm{O}$ of standards 2 and 3 there is no concentration effect, but a small dependence did appear for the more depleted standard $\left(-0.33 \% \circ 10000 \mathrm{ppmv}^{-1} ; R^{2}=0.75\right)$. For $\delta \mathrm{D}$, we found significant regression coefficients $\left(R^{2}=0.98,0.99\right.$ and 1.00 for standards 1, 2 and 3 respectively), and the slope of the dependence was only slightly different between standards (between 7.8 and $8.1 \%$ o $10000 \mathrm{ppmv}^{-1}$ ).

This justifies the use of only one standard (standard 1) to perform the very time-consuming daily calibration of the water concentration effect (160 min for a three-point cali- bration). Measurements are corrected for concentration dependence before applying the isotopic calibration in order to drive back atmospheric measurements to the water vapour concentration $w_{\text {reference }}$ at which standards are measured as follows (Schmidt et al., 2010):

$\delta_{\text {reference }}=\delta_{\text {observed }}+m \cdot\left(w_{\text {reference }}-w_{\text {observed }}\right)$,

where $\delta_{\text {reference }}(\% o)$ is the reference $\delta$ value at $w_{\text {reference }}$ (20000 ppmv in our case); $\delta_{\text {observed }}(\% o$ ) is the observed $\delta$ value at $w_{\text {observed }}$ (ppmv) the observed concentration; $m$ $\left(\% \circ \mathrm{ppmv}^{-1}\right)$ is the slope of the concentration dependence (Table 2).

\subsection{Instrument stability}

To evaluate the long-term stability of our instrument, statistics were calculated on raw delta values measured on our three standards during the entire field measurements (Table 1). Results show that the long-term variability is very low, but a regular calibration is nevertheless performed. Variability of both calibrations (for water vapour concentration and isotopic composition) is shown in Table 2. For $\delta^{18} \mathrm{O}$, the calibration for concentration appears highly variable but often flat (no concentration effect), resulting in a linearity which is not always significant $\left(0.26 \leq R^{2} \leq 1.00\right)$. Thus, $\delta^{18} \mathrm{O}$ was corrected only when the concentration dependence was significant. For $\delta \mathrm{D}$, the regression is slightly variable in the long-term, and its linearity is always significant $\left(0.89 \leq R^{2} \leq 0.99\right)$. For daily calibration in isotopic composition (normalization to the VSMOW2-SLAP2 scale), we used a three-point calibration, which allows to check for the linearity of the calibration. Linear regressions between raw measured values and absolute standard compositions are established as follows for $\delta^{18} \mathrm{O}$ and $\delta \mathrm{D}$ :

$\delta_{\text {calibrated }}=$ slope $\cdot \delta_{\text {measured }}+$ intercept.

Regressions are stable in the long-term (Table 2), and their linearity is always significant $\left(R^{2}=1.00\right)$. Accuracy and precision of our instrument, estimated by considering standard 2 as a sample which has been calibrated with standards 1 and 3, show good results (Table 3). These performances are estimated on liquid measurements, and are probably lower for vapour measurements.

\section{Local atmospheric data}

Hourly air temperature and relative humidity were measured at the study site. Hourly wind speed and daily PET (Potential Evapotranspiration calculated from the PenmanMonteith formula (Monteith, 1965)) were obtained from a meteorological station located $400 \mathrm{~m}$ far from the site of isotopic measurements. In addition, surface temperature was also measured in the main pond of the Vaccarès lagoon system at hourly time step. 
Table 2. Evaluation of the stability of the calibrations in water vapour concentration and isotopic composition, with mean slope and mean intercept \pm 1 standard deviation obtained for $\delta^{18} \mathrm{O}$ and $\delta \mathrm{D}$ with $n$ calibrations performed from 20 July to 24 August 2011.

\begin{tabular}{lcc}
\hline & $\delta^{18} \mathrm{O}$ & $\delta \mathrm{D}$ \\
\hline \multicolumn{2}{c}{ Water vapour concentration } \\
\hline Slope & $-0.16 \times 10^{-4} \pm 0.13 \times 10^{-4}$ & $6.08 \times 10^{-4} \pm 0.99 \times 10^{-4}$ \\
Intercept & $-13.68 \pm 0.25$ & $-165.4 \pm 2.0$ \\
$R^{2}(n=23)$ & $0.26 \leq R^{2} \leq 1.00$ & $0.89 \leq R^{2} \leq 0.99$ \\
\hline \multicolumn{3}{c}{ Isotopic composition } \\
\hline Slope & $1.03 \pm 0.01$ & $0.98 \pm 0.01$ \\
Intercept & $-2.83 \pm 0.07$ & $16.3 \pm 1.7$ \\
$R^{2}(n=40)$ & 1.00 & 1.00 \\
\hline
\end{tabular}

Table 3. Results of standard 2 measurements $\left(\delta_{\text {std } 2-m}\right)$ normalized to the VSMOW2-SLAP2 scale by using standards 1 and 3 as working standards, following the IAEA Reference Sheet (IAEA, 2009). Statistics are calculated from the set of 40 calibrations. Standard deviation provides the reproducibility, and the root mean square deviation from the known value (RMSE) provides the accuracy of liquid measurements.

\begin{tabular}{lccc}
\hline & $\begin{array}{c}\delta^{18} \mathrm{O} \\
(\% \circ \text { VSMOW })\end{array}$ & $\begin{array}{c}\delta \mathrm{D} \\
(\% \circ \text { VSMOW })\end{array}$ & $\begin{array}{c}d \\
(\% \circ)\end{array}$ \\
\hline Average of $\delta_{\text {std2-m }}$ & -7.82 & -53.4 & 9.16 \\
Standard deviation & 0.117 & 0.89 & 1.29 \\
RMSE & 0.121 & 0.89 & 1.30 \\
\hline
\end{tabular}

Regional advection conditions were determined for each individual day by computing backward three-dimensional trajectories with the Internet-based NOAA HYSPLIT Trajectory Model (http://ready.arl.noaa.gov/HYSPLIT.php). The HYSPLIT (Hybrid Single-Particle Lagrangian Integrated Trajectory) model is a complete system, which allows computing simple air parcel trajectories using GDAS (Global Data Assimilation System) meteorological data. Trajectories were initialized at the station location every $24 \mathrm{~h}$ at 12:00 UTC, at three heights $(50,100$ and $500 \mathrm{~m})$ above ground level. A minimum back-run time of $72 \mathrm{~h}$ was computed, and extended, when necessary, in order to reach either the Mediterranean Sea, or the Atlantic ocean (depending of the wind regime, a maximum of $144 \mathrm{~h}$ was computed). The air mass trajectories were consistent between the three different initial altitudes, and hourly data were then classified, on a daily basis (i.e. from 00:00 to 23:00 UTC), according the three air mass origins represented in Fig. 1: Mediterranean, North Atlantic, or Bay of Biscay.

Planetary boundary layer heights were obtained from GDAS meteorological data ( $3 \mathrm{~h}$ time step). They were extracted and interpolated to our specific station using the MeteoInfo software (www.meteothinker.com).
In addition, we collected and analysed three rainfall samples corresponding to four small rainfall events $(25,26$, 27 July, 7 August 2011). These samples account for a total of $7.6 \mathrm{~mm}$ of the $9.6 \mathrm{~mm}$ of cumulated rainfall during the measurement campaign; the remaining $2 \mathrm{~mm}$ correspond to eight very small events between 14 and 23 August (not sampled).

\section{Results and discussion}

The mean composition of atmospheric water vapour during the campaign is $\delta^{18} \mathrm{O}=-14.66 \%, \delta \mathrm{D}=-95.4$ and $d=21.9 \%$, with significant daily variations, from $\delta^{18} \mathrm{O}=-19.22$ to $-9.96 \%$ and $\delta \mathrm{D}=-125.2$ to $-61.7 \%$, while $d$ varies between 7.8 and $31.2 \%$ (Fig. 3). These deuterium excess values are higher than those of our three rainfall samples: $5.6,4.5$ and $7.0 \%$, (for $\delta^{18} \mathrm{O}=-3.89,-3.7$, and $-0.66 \%$ respectively), and also higher than the longterm average composition of regional precipitation in the neighbouring GNIP (Global Network of Isotopes in Precipitation) station (Avignon, $\approx 50 \mathrm{~km}$ far from the experimental site; $d=9.2 \%$ ). The composition of vapour in equilibrium with rainfall is plotted for comparison (Fig. 3). Values slightly enriched in ${ }^{18} \mathrm{O}$ compared to measured $\delta_{\mathrm{v}}$ suggest a probable evaporation of rainfall in the atmosphere, a classical feature for small summer rainfall events (Celle-Jeanton et al., 2001), while values slightly depleted in deuterium compared to measured $\delta_{\mathrm{v}}$ points to the influence of an enriched vapour at ground level.

In measured atmospheric vapour composition, substantial day-to-day variations of $\delta_{\mathrm{v}}$ are observed, while $d$ presents high hourly variations (Fig. 3). In order to explore the relevant time scales to interpret isotopic data in terms of synoptic and mesoscale meteorology vs. local influences, we first analyse the relations of our data to daily climatic variables and air mass origins. Then, we focus on average diurnal variations to identify the local influences. 
Table 4. Determination coefficients $\left(R^{2}\right)$ and slopes $(S)$ of linear correlations between daily means of water vapour composition $\left(\delta^{18} \mathrm{O}, \delta \mathrm{D}\right.$, $d)$ and air temperature $\left(T_{\mathrm{a}}\right)$, mixing ratio $(q)$, relative humidity at air temperature $\left(\mathrm{RH}_{\mathrm{a}}\right)$ and relative humidity at water surface temperature $\left(\mathrm{RH}_{\mathrm{S}}\right)$.

\begin{tabular}{lccccccccc}
\hline & \multicolumn{2}{c}{$\delta^{18} \mathrm{O}(\%)$} & & \multicolumn{2}{c}{$\delta \mathrm{D}(\%)$} & & \multicolumn{2}{c}{$d(\% \circ)$} \\
\cline { 2 - 3 } \cline { 8 - 9 } \cline { 8 - 9 } & $R^{2}$ & $S$ & & $R^{2}$ & $S$ & & $R^{2}$ & $S$ \\
\hline$T_{\mathrm{a}}\left({ }^{\circ} \mathrm{C}\right)$ & 0.30 & +0.54 & & 0.27 & +3.48 & & 0.20 & -0.88 \\
$q\left(\mathrm{mmol} \mathrm{mol}{ }^{-1}\right)$ & 0.72 & +0.38 & & 0.62 & +2.39 & & 0.54 & -0.66 \\
$\mathrm{RH}_{\mathrm{a}}(\%)$ & 0.64 & +0.13 & & 0.55 & +0.80 & & 0.51 & -0.23 \\
$\mathrm{RH}_{\mathrm{S}}(\%)$ & 0.33 & +0.13 & & 0.31 & +0.83 & & 0.19 & -0.19 \\
\hline
\end{tabular}

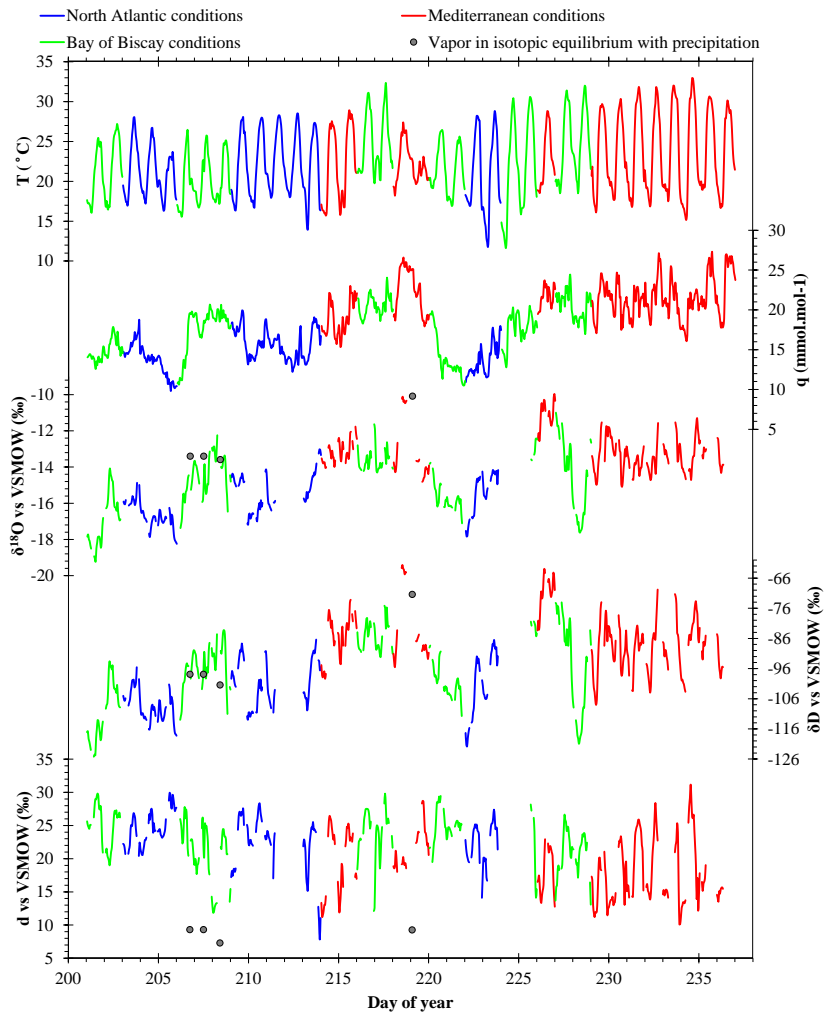

Figure 3. Hourly time series of air temperature $(T)$, mixing ratio $(q), \delta^{18} \mathrm{O}, \delta \mathrm{D}$, deuterium excess $(d)$ from 20 July to 24 August 2011 at the experimental site according to air mass origin (see Fig. 1). Grey dots are $\delta_{\mathrm{v}}$ and $d$ values calculated from the isotopic equilibrium with precipitation.

\subsection{Correlations between isotope data and local climatic parameters}

Quite good correlations are found between daily values of $\delta_{\mathrm{v}}$ and local climatic parameters (Table 4 ), the best fit being with the mixing ratio $q,\left(R^{2}=0.72\right.$ and 0.62 for $\delta^{18} \mathrm{O}$ and $\delta \mathrm{D}$ respectively). Such a correlation could result from the case of simple Rayleigh rainout processes, where condensation phases progressively remove water from the atmosphere and deplete the remaining atmospheric vapour in heavy iso- topes (Dansgaard, 1964; Lee et al., 2006; Wen et al., 2010). The progressive rainout follows a temperature decrease, and should also result in a correlation between $\delta_{\mathrm{v}}$ and $T$, and subsequently between rainfall isotope content $\left(\delta_{\mathrm{p}}\right)$ and $T$, which has led to the establishment of the isotopic thermometer (Dansgaard, 1964; Jouzel et al., 1997). Our data show a relation between $\delta_{\mathrm{v}}$ and $T$ (Table 4, Fig. 3) close to the isotopic thermometer: $\Delta \delta^{18} \mathrm{O} / \Delta T=0.53 \%{ }^{\circ} \mathrm{C}^{-1}$ (Jouzel et al., 1997), but the correlation is relatively poor $\left(R^{2}=0.30\right)$, indicating more complex processes, as was observed during a long-term German survey in which $\delta_{\mathrm{v}}-T$ correlation was degraded during summer because of the admixture of vapour originating from plant transpiration (Jacob and Sonntag, 1991). Since the correlation between $\delta_{\mathrm{v}}$ and $q$ is much stronger than the $\delta_{\mathrm{v}}-T$ correlation, it indicates a mixing between air masses characterized by different vapour concentrations, as could result from different marine origins and/or from the addition of continental vapour into the atmosphere.

With respect to deuterium excess, we found that $q$ is also the best predictor of $d$ variations at a daily time step $\left(R^{2}=0.54\right.$, Table 4$)$. In addition, we observed a correlation between $d$ and $\mathrm{RH}_{\mathrm{a}}\left(R^{2}=0.51\right)$, consistent with Welp et al. (2012), but the correlation becomes very low $\left(R^{2}=0.19\right)$ when using relative humidity at surface temperature $\left(\mathrm{RH}_{\mathrm{s}}\right)$. The significance of deuterium excess in terms of a proxy for the conditions at the vapour sources comes from the fact that it is determined by the kinetic isotopic fractionation that occurs during evaporation. The kinetic fractionation mainly depends on relative humidity at the water surface, which represents the vapour concentration gradient between the liquidvapour interface and free air (Craig and Gordon, 1965; Gonfiantini, 1986; Pfahl et Wernli, 2008; Uemura et al., 2008). Relative humidity is not conservative during air mass transport, as temperature changes modify the saturated vapour pressure, and the value measured at the meteorological station has to be reported at surface temperature.

Starting from a value around $d=0 \%$ in ocean water, the kinetic fractionation associated to the initial seawater evaporation produces an increase in $d$ in oceanic vapour inversely related to humidity conditions (Merlivat and Jouzel, 1979; Armengaud et al., 1998; Pfahl et Wernli, 2008; Uemura et al., 2008; Jouzel et al., 2013; Steen-Larsen et al., 2013). 

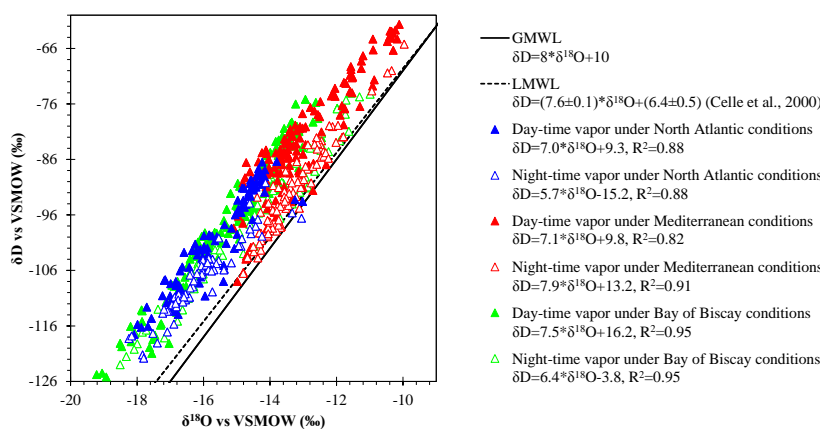

Figure 4. Hourly daytime and night-time isotopic composition of atmospheric water vapour according to air mass origins. For reference, the Global Meteoric Water Line (GMWL) and Local Meteoric Water Line (LMWL) are also plotted.

During the air mass trajectory over land, $d$ may be further increased by the addition of vapour of continental origin (Gat and Matsui, 1991; Gat et al., 1994; Angert et al., 2008; Lai and Ehleringer, 2011; Welp et al., 2012). This "secondary" vapour is also expected to carry a $d$ value inversely related to humidity conditions at the vapour source (Aemisseger et al., 2014). However, the lack of correlation between $d$ and $\mathrm{RH}_{\mathrm{s}}$ in our data, whilst the $d-q$ correlation is stronger, suggests, as was the case for the $\delta_{\mathrm{v}}-q$ correlation, that mixing processes between air masses characterized by different vapour origins and concentrations have weakened the $d-\mathrm{RH}_{\mathrm{s}}$ relation.

Since it is hardly modified by equilibrium condensation, $d$ can be considered as a conservative tracer of vapour sources during mixing processes. Nevertheless, the conservative behaviour of $d$ during rainout is perturbed by the non-linearity in the definition of deuterium excess: the delta-notation approximation induces a small shift in $d$ when there is a large decrease in $\delta^{18} \mathrm{O}$ and $\delta \mathrm{D}$ (Gat et al., 1996; Angert et al., 2008; Welp et al., 2012). In the observed range of $\delta^{18} \mathrm{O}$ (from -11 to $-18 \%$ o), we have estimated this effect to induce a $2.5 \%$ o increase in $d$, while the substantial variations in $d$ observed in our daily data are significantly higher (from 15 to $26 \%$ ), allowing the use of $d$ as a tracer of different vapour pools.

\subsection{Regional isotopic signatures}

In order to examine the link between the isotopic characteristics of vapour and the air mass origin, we analyse the data classified according to the three main backward trajectories schematically represented in Fig. 1 (see Sect. 3). Corresponding hourly data are scattered in the $\delta^{18} \mathrm{O}-\delta \mathrm{D}$ plot distinctly above the local meteoric water line (LMWL, Fig. 4), and show isotopically depleted compositions for air masses coming from the North Atlantic, while air masses coming from the Mediterranean Sea display isotopically enriched vapour (Table 5, Fig. 4). For air masses coming from Bay of Biscay, hourly data encompass the entire isotopic range. Local
Table 5. Number of days $(n)$ associated with the different origins of air masses (Fig. 1). Corresponding mean values of $\delta^{18} \mathrm{O}, \delta \mathrm{D}$, deuterium excess $(d)$, air temperature $\left(T_{\mathrm{a}}\right)$, mixing ratio $(q)$, relative humidity $(\mathrm{RH})$, wind speed $(V)$ and potential evapotranspiration (PET) measured in the experimental site.

\begin{tabular}{lccc}
\hline & $\begin{array}{c}\text { North Atlantic } \\
\left(310-360^{\circ}\right)\end{array}$ & $\begin{array}{c}\text { Mediterranean } \\
\left(110-220^{\circ}\right)\end{array}$ & $\begin{array}{c}\text { Bay of Biscay } \\
\left(220-310^{\circ}\right)\end{array}$ \\
\hline$n$ & 10 & 13 & 13 \\
$\delta^{18} \mathrm{O}(\%)$ & -15.83 & -13.13 & -14.90 \\
$\delta \mathrm{D}(\% \circ)$ & -103.5 & -86.5 & -96.3 \\
$d(\% \circ)$ & 23.2 & 18.6 & 22.9 \\
$T_{\mathrm{a}}\left({ }^{\circ} \mathrm{C}\right)$ & 21.6 & 23.3 & 22.3 \\
$q\left(\mathrm{mmol} \mathrm{mol}^{-1}\right)$ & 15.0 & 21.8 & 18.0 \\
$\mathrm{RH}(\%)$ & 59.5 & 78.5 & 68.1 \\
$V\left(\mathrm{~m} \mathrm{~s}^{-1}\right)$ & 2.0 & 0.7 & 1.6 \\
PET $\left(\mathrm{mmday}^{-1}\right)$ & 5.8 & 3.8 & 4.9 \\
\hline
\end{tabular}

climatic data associated with the three meteorological situations reflect synoptic weather conditions related to air mass origins. Air masses coming from the North Atlantic are associated with strong, cold and dry winds, while those from the Mediterranean are associated on the contrary with light, warm and wet winds (Table 5). The Bay of Biscay is an intermediate situation. It thus appears that the greater the distance over land (Fig. 1), the more depleted $\delta_{\mathrm{v}}$. The northern trajectory corresponds to a "Mistral" situation: a typical strong north-northwest wind that affects the north of the occidental Mediterranean basin 130 days a year on average. The air mass is gradually dried out by rainout processes over land and accelerated in the Rhône River valley and acquires a depleted isotopic signature. On the contrary, an air mass travelling over the Mediterranean Sea with the slight thermal wind or sea breeze coming from the south is moistened and acquires and maintains an enriched isotopic signature.

With respect to $d$, North Atlantic air masses bring higher values (23.2\%o) than Mediterranean air masses (18.6\%o), but the main feature, which appears on the $\delta^{18} \mathrm{O}-\delta \mathrm{D}$ plot (Fig. 4), is the distinct separation between nocturnal and diurnal hourly data, with the latter plotting higher above the meteoric lines. This feature is observed for each of the three air mass origins.

Within these three classes of data, strong linear relationships are observed (Fig. 4), with slopes lower than eight, a value attributed to thermodynamic equilibrium, as it approximately represents the average ratio between $D$ and ${ }^{18} \mathrm{O}$ liquid-vapour equilibrium fractionation. Such low slopes have also been observed in atmospheric vapour from Hawaii (7.02 (Bailey et al., 2013)), Greenland (between 6.47 and 7.44 (Steen-Larsen et al., 2013)), western Siberia (between 5.6 and 7.7 (Bastrikov et al., 2014)), and in North America (7.5 (Berkelhammer et al., 2013)). The previously described shift in $d$ during Rayleigh-type rainout, due to the nonlinearity in the deuterium excess definition, is not sufficient to explain these low slopes, and non-equilibrium processes 

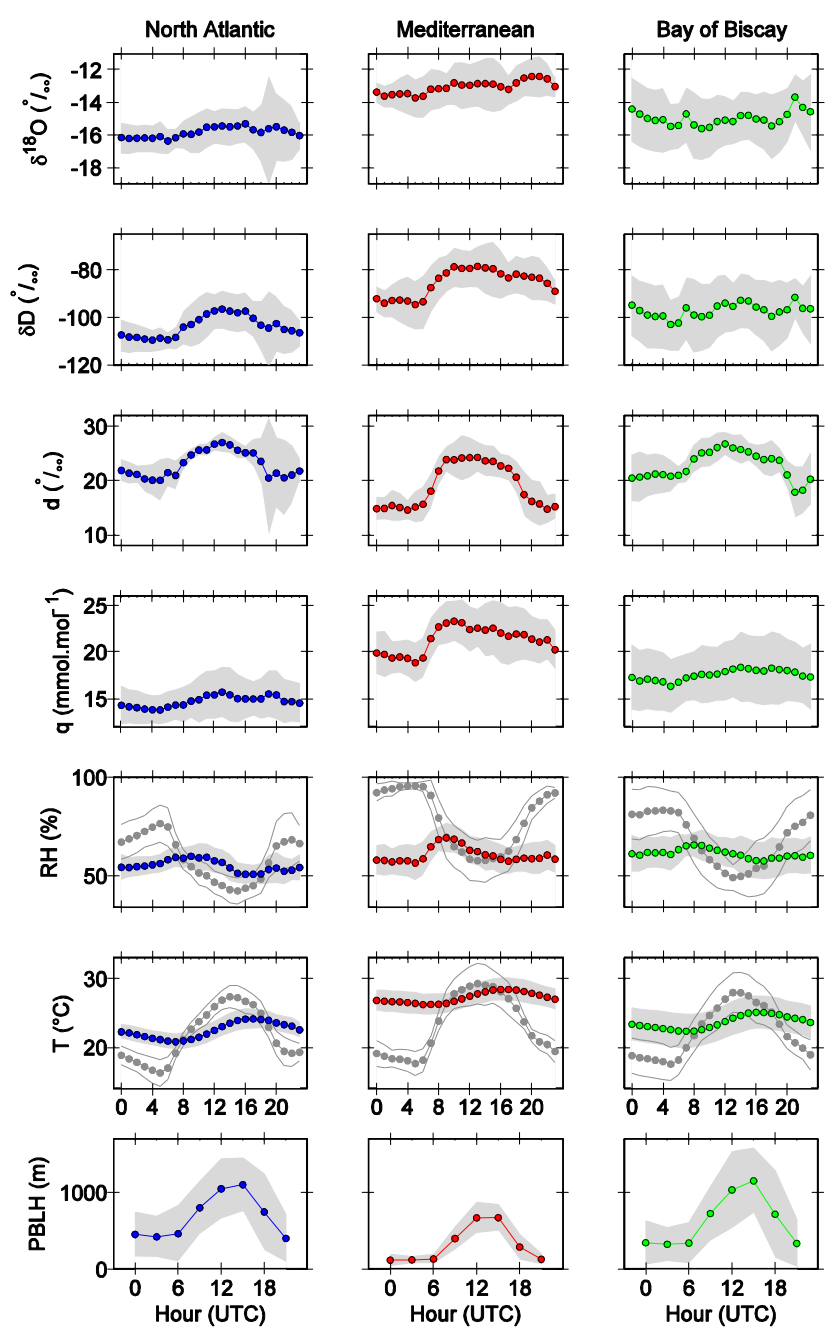

Figure 5. Average daily cycles of $\delta^{18} \mathrm{O}, \delta \mathrm{D}$, deuterium excess $(d)$, relative humidity at surface $\left(\mathrm{RH}_{\mathrm{s}}\right)$ and air $\left(\mathrm{RH}_{\mathrm{a}}\right.$, grey symbols) temperature, surface $\left(T_{\mathrm{S}}\right)$ and air $\left(T_{\mathrm{a}}\right.$, grey symbols) temperature, mixing ratio $(q)$ and planetary boundary layer height (PBLH) calculated from 20 July to 24 August 2011 according to the three air mass origins. Grey shading indicates standard deviation of each average value.

such as evaporation are also probably involved (Gibson et al., 2008).

\subsection{Analysis of average daily cycles}

In order to observe the diurnal variations suggested by the night-day separation, average daily cycles of isotopic and climatic data are plotted for the three air mass origins (Fig. 5). A well-pronounced cyclicity appears for $d$ in each meteorological condition. For the Bay of Biscay origin, the average $d$ cycle is very similar to the North Atlantic case, with larger standard deviations, reflecting a more variable climatic situation. For Mediterranean conditions, the $d$ cycle is higher in amplitude than for North Atlantic conditions, and lower in absolute values, especially during the night. The high standard deviations observed during the last hours of the day correspond to calibration periods for which there are fewer data, but may also be due to variations in the timing of the PBL evening transition. The increase in $d$ during the morning is mainly associated with a $\delta \mathrm{D}$ increase, while $\delta^{18} \mathrm{O}$ variations are smoother. Amplitudes of daily isotopic variations are higher for Mediterranean conditions (9.7, 16.2 and $1.3 \%$ for $d, \delta \mathrm{D}$ and $\delta^{18} \mathrm{O}$ respectively) than for North Atlantic ones (7.0, 13.1 and $1.1 \%$ for $d, \delta \mathrm{D}$ and $\delta^{18} \mathrm{O}$ respectively).

From a climatic point of view, we observe high diurnal variations in $\mathrm{RH}_{\mathrm{a}}$, mainly driven by the large amplitude of air temperature variations between night and day (Fig. 5). As discussed above, the significance of relative humidity conditions in terms of evaporation conditions - and deuterium excess control - is only relevant at surface temperature. The variations are smoother for $\mathrm{RH}_{\mathrm{s}}$, and it more or less follows the absolute amount of water (Fig. 5). Under Mediterranean conditions, a distinct increase of $q$ occurs in the morning, indicating a net addition of vapour in the atmosphere. Under North Atlantic conditions, the $q$ increase is lower, but still detectable.

The daily cyclicity of the planetary boundary layer height (PBLH) is specifically related to the different atmospheric conditions. The PBLH attains around $1100 \mathrm{~m}$ on average during the afternoon under North Atlantic and Bay of Biscay conditions, with a significant standard deviation. Under Mediterranean conditions, the PBLH is less variable and remains at almost $700 \mathrm{~m}$. Nocturnal values are also very low - less than $100 \mathrm{~m}$ - in Mediterranean conditions, compared to $400-500 \mathrm{~m}$ in the other weather situations (Fig. 5). Low PBLH in Mediterranean conditions corresponds to weak turbulence and air stability resulting from light winds, while northerly advection transports a relatively cold air mass over a warmer surface, leading to a weaker stratification.

\subsubsection{Daytime processes: contribution of local evaporation}

The diurnal increase in $d$ is a widely observed feature, which reflects the diurnal variation of the water and air mass balances of the planetary boundary layer (Lai and Ehleringer, 2011). This increase can be caused by the entrainment of free atmosphere into the boundary layer (Zhang et al., 2011; Welp et al., 2012; Berkelhammer et al., 2013), but also by the addition of locally evaporated vapour. The direction of vapour concentration changes associated with these $d$ variations can help to identify which of these two processes dominates the PBL water mass budget. Entrainment brings a dryer air into the PBL, and thus causes a daytime decrease in vapour concentration, while an increase in mixing ratio indicates the addition of an evaporation flux. Note that the transpiration component of evapotranspiration is not expected to carry high $d$, as it has the same isotopic composition as the 
soil water at steady state (Yakir and Wang, 1996; Williams et al., 2004). In addition, the free atmospheric air is characterized by a isotopically lighter vapour (He and Smith, 1999; Bailey et al., 2013; Berkelhammer et al., 2013), and the dominance of entrainment during daytime is generally associated with a $\delta_{\mathrm{v}}$ depletion (Lai et al., 2006; Lai and Ehleringer, 2011; Tremoy et al., 2012; Bailey et al., 2013; Berkelhammer et al., 2013). Welp et al. (2012) compared six measurement locations and found that both local evapotranspiration and entrainment were involved: in some of their sites, the $d$ daily increase was associated with a $\delta^{18} \mathrm{O}$ decrease during the early morning due to entrainment of free atmosphere into the boundary layer during convective mixing, while the subsequent slight $\delta^{18} \mathrm{O}$ increase came from evapotranspiration. Our data display a simultaneous increase in $q, \delta^{18} \mathrm{O}$ and $\delta \mathrm{D}$ (Fig. 5), and thus indicate that the addition of surface vapour is the dominant process governing the $d$ cyclicity during the day.

\subsubsection{Nocturnal processes: dew formation}

In each meteorological situation, $d$ displays an abrupt decrease at around 20:00 UTC, which corresponds to the timing of sunset. Afterwards, during the 20:00-06:00 UTC period, $d$ remains low, while $\delta_{\mathrm{v}}$ follows a gradual depletion associated with a $q$ decrease (Fig. 5). This corresponds to the effect of a progressive Rayleigh-condensation process, and indicates the formation of dew induced by the nocturnal cooling of soil and/or leaves surfaces, as was observed by Berkelhammer et al. (2013).

A small nocturnal evaporation of the lagoon water could nevertheless occur since the water surface temperature remains high and maintains $\mathrm{RH}_{\mathrm{s}}$ below saturation (Fig. 5), but it is expected to remain low compared to daytime fluxes. During the night, the PBL subsidence corresponds to the reduction of both the surface heat fluxes and entrainment, and the addition of water vapour to the atmosphere, if any, remains low. The large-scale motion becomes dominant and, without changing the total PBL mass, redistributes it horizontally (Medeiros et al., 2005). The nocturnal isotopic values thus represent the average composition of the PBL, onto which are superimposed daytime fluxes. More precisely, since dew formation is a local process, the value measured just after the sunset (20:00 UTC), when the PBL collapses, is probably the most representative composition of the average $\mathrm{PBL}$, with the greater proportion of regional water vapour. The high $d$ values observed during the night (on average $15.1 \pm 0.5 \%$ o under Mediterranean conditions and $20.9 \pm 0.7 \%$ o under North Atlantic conditions), thus result from the remaining imprint of local evaporation, combined with the signature of the regional atmosphere.

\subsection{Local isotopic signatures}

The concomitant increase of $q$ and $d$ during daytime in our average diurnal cycles indicates that the $d$ cyclicity is mainly driven by the addition of surface vapour fluxes. As stated above, the location of the experimental site close to the main lagoon, and the availability of large open water areas in the surroundings point to a dominant contribution of evaporation over transpiration. In order to calculate the isotopic composition of the locally evaporated vapour $\left(\delta_{\mathrm{E}}\right)$, we use a twocomponent mixing model based on the linear correlation between $1 / q$ and $\delta_{\mathrm{v}}$, derived from the "Keeling plot" method. The ability of this simple model to describe our data and the possible contribution of regional advection is then discussed. The original Keeling approach (Keeling, 1958) was initially proposed to describe the addition of $\mathrm{CO}_{2}$ into the atmosphere, and then further used to determine the isotopic composition of evapotranspired vapour flux (Yakir and Sternberg, 2000; Yepez et al., 2003; Williams et al., 2004; Wang et al., 2010; Zhang et al., 2010; Noone et al., 2011, 2013; Lee et al., 2012; Griffis et al., 2013). Assuming a background represented by an initial air quantity with a mixing ratio $q_{\mathrm{BG}}$ $\left(\mathrm{mmolmol}{ }^{-1}\right)$, and taking $n_{\mathrm{A}}(\mathrm{mol})$ the corresponding dry air amount, the addition of water vapour $n_{\mathrm{E}}(\mathrm{mmol})$ leads to the following mixing equation:

$q=q_{\mathrm{BG}}+\frac{n_{\mathrm{E}}}{n_{\mathrm{A}}}$,

where $q$ is the mixing ratio $\left(\mathrm{mmol} \mathrm{mol}^{-1}\right)$ of the resulting humid air (note that $n_{\mathrm{E}} / n_{\mathrm{A}}$ does not represent a mixing ratio despite same units). Attributing an isotopic composition to each of these vapour pools, $\delta_{\mathrm{BG}}$ for the background vapour and $\delta_{\mathrm{E}}$ for the added vapour, the corresponding isotopic mass balance is

$\delta_{\mathrm{v}}=\left(\delta_{\mathrm{BG}}-\delta_{\mathrm{E}}\right) \cdot \frac{q_{\mathrm{BG}}}{q}+\delta_{\mathrm{E}}$,

where $\delta_{\mathrm{v}}$ is the vapour composition of the resulting atmosphere. In a data set tracing the progressive addition of pure vapour in a closed system, and assuming an isotopically stable background, the $\delta_{\mathrm{v}}$ vs. $1 / q$ relationship displays a linear trend. The composition of the added vapour $\delta_{\mathrm{E}}$ is therefore deduced from the intercept (for $q \rightarrow \propto$ ).

However, when the increase in water vapour concentration results from the mixing with a humid air mass, Eq. (3) becomes

$q=x q_{\mathrm{BG}}+(1-x) q_{\mathrm{E}}$,

where $x$ is the fraction of the initial background air, and $q_{\mathrm{E}}$ is the mixing ratio of the added air mass $\left(\mathrm{mmol} \mathrm{mol}^{-1}\right)$. Thus, the corresponding expression for $\delta_{\mathrm{v}}$ is

$\delta_{\mathrm{V}}=\left(\delta_{\mathrm{BG}}-\delta_{\mathrm{E}}\right) \cdot \frac{x q_{\mathrm{BG}}}{q}+\delta_{\mathrm{E}}$. 


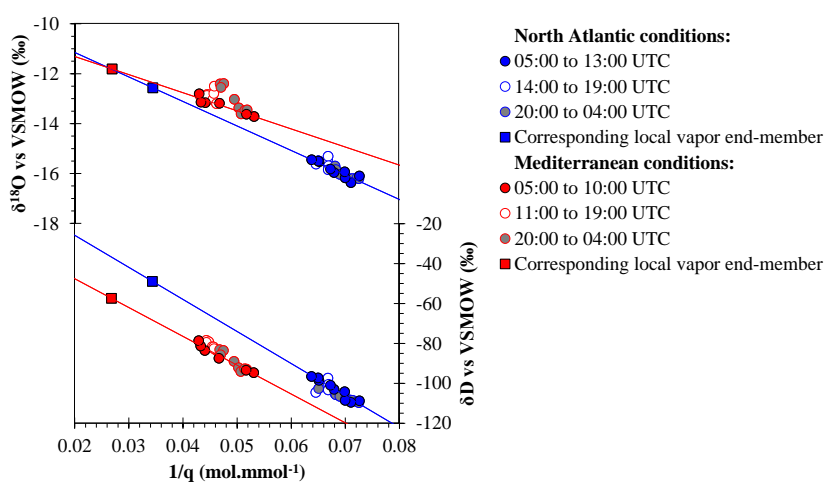

Figure 6. Relationships between hourly average values of $\delta_{\mathrm{V}}$ and $1 / q$ over a daily cycle according to the two main air mass origins, and corresponding linear regressions for the period of $q$ increase $\left(\delta^{18} \mathrm{O}=-98.1 \cdot(1 / q)-9.2\left(R^{2}=0.84\right), \delta \mathrm{D}=-1606.7 \cdot(1 / q)+\right.$ $6.3\left(R^{2}=0.93\right)$ for North Atlantic conditions, and $\delta^{18} \mathrm{O}=-72.4$. $(1 / q)-9.9\left(R^{2}=0.89\right), \delta \mathrm{D}=-1444.8 \cdot(1 / q)-18.7\left(R^{2}=0.96\right)$ for Mediterranean conditions). Squares indicate the isotopic composition of the local end-member $\left(\delta_{\mathrm{E}}\right)$ calculated for a mixing ratio corresponding to saturation at the water surface temperature.

The composition of the added vapour is then deduced from the $\delta_{\mathrm{v}}$ vs. $1 / q$ plot for $x=0$, i.e. for $q=q_{\mathrm{E}}$, and the mixing ratio of the added air $\left(q_{\mathrm{E}}\right)$ is a prerequisite for applying this two-component mixing model. For a humid air mass coming from open water evaporation, a mixing ratio corresponding to saturation conditions at the liquid-vapour interface $\left(q_{\mathrm{E}}=q_{\mathrm{s}}\right)$ can be considered as representing the limit condition (Craig and Gordon, 1965; Noone et al., 2011; Noone, 2012).

Our discussion will focus on the two most contrasted meteorological situations, i.e. Mediterranean and North Atlantic air mass origins. Strong correlations are found between average values of $\delta_{\mathrm{v}}$ and $1 / q$ for the period of $q$ increase, i.e. 05:00-13:00 UTC for North Atlantic situations and 05:00-10:00 UTC for Mediterranean situations $\left(R^{2}\right.$ values are between 0.85 and 0.96 , see Fig. 6). The local endmembers are calculated for the average value of saturation mixing ratio at the water surface temperature $\left(q_{\mathrm{s}}\right)$, during the daily maximum air water concentrations (at 13:00 or 10:00 UTC). Uncertainties are determined as resulting from error propagation of the linear model in the whole range of $q_{\mathrm{s}}$ standard deviation. The resulting compositions of local endmembers $\left(\delta_{\mathrm{E}}\right)$ are $\delta^{18} \mathrm{O}=-12.5 \%$ o ( -11.0 to $-13.9 \%$ ); $\delta \mathrm{D}=-48 \%$ ( $(-30$ to $-64 \%$ ) for North Atlantic conditions, $\delta^{18} \mathrm{O}=-11.8 \%$ o $(-11.0$ to $-12.5 \%$ ) $; \delta \mathrm{D}=-58 \%$ o $(-46$ to $-68 \%$ ) for Mediterranean conditions (Fig. 7). High deuterium excess values characterize the surface vapour for North Atlantic $(d=52 \pm 29 \% o)$ and Mediterranean conditions ( $37 \pm 17 \%$ o), which is consistent with previous estimates from the Craig and Gordon model (Craig and Gordon, 1965; Gat et al., 1994). Such high $d$ is a characteristic of vapour coming from continental evaporation and allowed to detect the contribution of continental vapour to regional precipita-
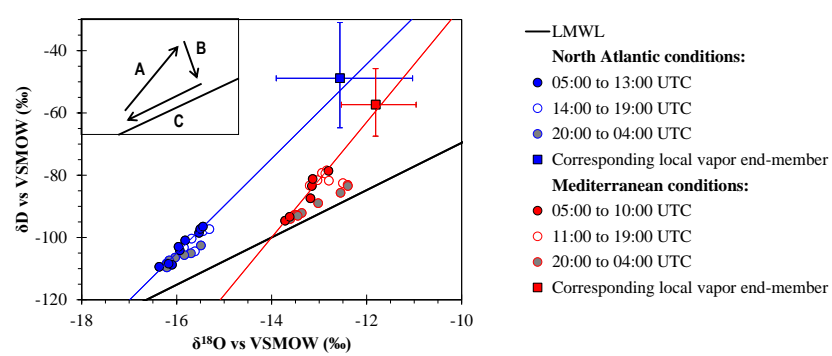

Figure 7. Hourly average values of $\delta \mathrm{D}$ vs. $\delta^{18} \mathrm{O}$ over a daily cycle, according to the two main air mass origins, corresponding linear regressions for the period of $q$ increase (see text), and calculated local end-member $\left(\delta_{\mathrm{E}}\right)$. For reference, the LMWL is also plotted.

tion (Gat et Matsui, 1991; Gat et al., 1994; Vallet-Coulomb et al., 2008). In our case, these high $d$ values confirm that evaporation is largely dominant over transpiration, and that the higher $d$ under North Atlantic air mass conditions is consistent with lower $\mathrm{RH}_{\mathrm{s}}$, compared to Mediterranean conditions (Fig. 5, Table 5).

Going on with the two end-member mixing assumption, this $\delta_{\mathrm{E}}$ composition could be used to interpret the amplitude of diurnal $\delta_{\mathrm{v}}$ variations in terms of the daily addition of locally evaporated vapour to the nocturnal background. The lower amplitude of diurnal variations observed under North Atlantic condition (Fig. 7) would then indicate a lower proportion of locally evaporated vapour in ambient moisture. However, this is not consistent with the stronger average potential evapotranspiration rates under North Atlantic conditions, compared to the Mediterranean situation: $5.8 \mathrm{vs}$. $3.8 \mathrm{~mm} \mathrm{day}^{-1}$ (Table 5). This apparent contradiction indicates that the isotopic imprint of local evaporation is diluted by advection, with a greater extend under Northern conditions than under Mediterranean conditions. This is fully consistent with the high wind speed characterizing North Atlantic conditions: an average value of $2.0 \mathrm{~m} \mathrm{~s}^{-1}$ compared to $0.7 \mathrm{~m} \mathrm{~s}^{-1}$ for Mediterranean conditions. Local vapour is thus flushed by advection of dry northward air masses, and since this advected vapour may carry a different isotopic signature than the nocturnal background, a simple two-component mixing model is not sufficient to describe the PBL water balance.

We have evaluated the impact of regional advection on the determination of $\delta_{\mathrm{E}}$, by testing different simulations of a three-component mixing process. Starting from the initial background $\left(\delta_{\mathrm{BG}}=\right.$ average $\delta_{\mathrm{v}}$ value at 05:00 UTC), we simulate the progressive addition of both regional advected vapour $\left(\delta_{\mathrm{R}}\right)$ and locally evaporated vapour $\left(\delta_{\mathrm{E}}\right)$, and we compare the resulting composition with observed $\delta_{\mathrm{v}}$ during the $q$-increase period of the day. For each simulation, we choose a hypothetical value of $\delta_{\mathrm{R}}$, and we adjust $\delta_{\mathrm{E}}$ in order to match the observed data on the $\delta_{\mathrm{v}}$ vs. $1 / q$ relationship, using a simple trial-and-error procedure, successively for $\delta^{18} \mathrm{O}$ and $\delta \mathrm{D}$. We have tested a range of $\delta_{\mathrm{R}}$ values compatible with the shift 
observed during sunset, on the $\delta^{18} \mathrm{O}-\delta \mathrm{D}$ plot (Fig. 7). As discussed previously, the $\delta_{\mathrm{v}}$ value measured at 20:00 UTC is expected to carry the lowest proportion of locally evaporated vapour. We thus postulate that the shift in $d$ observed at 20:00 ("B" arrow in Fig. 7) is "dragged" by the composition of a more regional vapour. We have then explored a domain of $\delta_{\mathrm{R}}$ values limited by (1) the 20:00 UTC value as an upper limit for $\delta \mathrm{D} ;(2)$ the 20:00 UTC (05:00 UTC) value as a lower limit for $\delta^{18} \mathrm{O}$ under Mediterranean (North Atlantic) conditions and (3) the LMWL. For each $\delta_{\mathrm{R}}$ value, different mixing ratio were tested $\left(q_{\mathrm{R}}\right)$, chosen to remain compatible with the midday-20:00 UTC trend observed on the $1 / q-\delta_{\mathrm{v}}$ plot. We found that in all cases, the $\delta_{\mathrm{E}}$ values remain in the range of the error bars shown in Fig. 7, with slightly lower $\delta^{18} \mathrm{O}$ and higher $d$.

The processes involved in the diurnal isotopic behaviour of atmospheric vapour can be summarized in the $\delta^{18} \mathrm{O}-\delta \mathrm{D}$ plot, which is a good mean to understand the drivers of $d$ variations (Fig. 7). The two clusters of average vapour data are distributed along two linear trends defined by the $q$-increase period of the day ("A" arrow in Fig. 7), which also meet the calculated value of $\delta_{\mathrm{E}}$. These trends result from the addition of locally evaporated vapour into the ambient air, but, as discussed above, are also influenced by the input of (and flushing by) regional advection. The daytime vapour composition then oscillates, but stays around the maximum $\delta_{\mathrm{v}}$ value, until the abrupt shift that occurs at 20:00 UTC, during sunset, consistently for both meteorological situations ("B" arrow in Fig. 7). The $d$ decrease observed when the PBL collapses, during sunset, corresponds to the weakening of surface evaporation, and to an increasing proportion of a more regional atmosphere. The night-time $\delta_{\mathrm{v}}$ evolves closer to the meteoric water line, compared to daytime compositions. The progressive condensation occurring between 20:00 and 05:00 UTC maintains the $\delta_{\mathrm{v}}$ along a regression line roughly parallel to the LMWL ("C" arrow in Fig. 7).

The stronger advection rate which prevails under North Atlantic conditions, and which smoothed the diurnal amplitude of $\delta_{\mathrm{v}}$ variation, suggests that the higher $d$ signature of water vapour (Table 5) results from the combined influences of higher $d$ in the locally evaporated vapour and in the regional vapour, consistently with the longer continental trajectory. A more precise determination of the regional vapour isotopic composition would rely on the quantification of advection fluxes and on a full PBL mass balance estimate.

\section{Conclusion}

Our results show that both local and regional isotopic signatures are recorded in the ground level atmospheric vapour composition, and that a sub-daily analysis is necessary to decipher these influences. After having classified the data according to air mass origins and trajectories, we found strong diurnal variations of $d$, with lower amplitude varia- tions under the influence of northern air masses than under Mediterranean influences. The higher average $d$ observed under northern conditions ( $23.2 \%$ compared to $18.6 \%$ or the Mediterranean situations) is mainly due to higher nocturnal values, while the daytime maxima are similar. However, the drivers of these diurnal variations have to be understood to interpret the isotopic signal with respect to its relevant spatiotemporal scales, and it is essential to understand and compare the behaviour of both $\delta^{18} \mathrm{O}$ and $\delta \mathrm{D}$ (referred to as $\delta_{\mathrm{v}}$ ) to understand $d$.

A diurnal increase in $d$ can be caused by entrainment of free atmospheric air, by surface evaporation, or by a combination of both processes. Unlike evaporation, the contribution of free atmospheric air would induce a decrease in absolute vapour concentration. Therefore, our average daily cycles clearly indicate that the diurnal increase in $d$ is essentially driven by local evaporation. Based on the robust alignment of average hourly data in a $\delta_{\mathrm{v}} \mathrm{vs} .1 / q$ plot for the $q$-increase period of the day, we applied a two-component mixing model to estimate the composition of locally evaporated vapour $\left(\delta_{\mathrm{E}}\right)$. Then, since regional advection modulates the amplitude of diurnal $\delta_{\mathrm{v}}$ variations, we discussed the twocomponent mixing assumption and evaluate the influence of a third component on the determination of $\delta_{\mathrm{E}}$. We show that it remains low, because the composition of regional advection is expected to be close to the nocturnal values. We found higher $d$ for the locally evaporated vapour under North Atlantic air mass conditions, which is consistent with lower humidity conditions, while the corresponding $\delta^{18} \mathrm{O}$ compositions are very similar between the two meteorological situations, with a difference of about $0.7 \%$.

In contrast, there is an important difference in the $\delta^{18} \mathrm{O}$ compositions between the two meteorological situations when considering the nocturnal values. More specifically, it is interesting to consider the ambient vapour composition measured at 20:00 UTC when the PBL collapses, and before the progressive influence of dew formation during the night. This 20:00 UTC composition is the least influenced by locally evaporated vapour, and the most representative of a regional signal. The difference in $\delta^{18} \mathrm{O}$ between the two main meteorological situations (upper than $3 \%$ o) reflects the influence of synoptic and mesoscale weather conditions, related to air mass origin and trajectory. Strong, cold and dry winds coming from the north bring an isotopically depleted vapour. Conversely, light, warm and wet winds coming from the south bring an isotopically enriched vapour. In addition, the strong advection rate that prevails under North Atlantic conditions suggests that, in this situation, the high average $d$ of water vapour at 20:00 UTC also reflects the signature of regional vapour.

In general, our data showed that the mixing ratio is a better predictor of deuterium excess variations than relative humidity, at both daily and sub-daily time scales, since mixing processes between different vapour sources weakened the relevance of relative humidity as an indicator of evaporation 
conditions. At the daily time step, the mixing ratio is a proxy for the air mass origin, since there is a huge contrast between water content of northern and Mediterranean air masses. At the sub-daily time step, a $\delta_{\mathrm{v}}-q$ correlation, and subsequently a $d-q$ correlation, during the $q$-increase period of the day, results from the addition of locally evaporated vapour. The general framework proposed in this study, for typical daily cycles of water vapour isotopic composition under different meteorological conditions, could be used in further quantitative analyses of vapour sources during specific days.

Acknowledgements. This work was performed in the framework of Hélène Delattre's $\mathrm{PhD}$. It was supported by CNRS-INSU (EC2CO-VISOTOP project, and contribution to the thesis grant), by "Region PACA" (contribution to the thesis grant, and to the Picarro instrument), by the Fédération de Recherche ECCOREV (contribution to the Picarro instrument and Eau-Trace project). We thank the "Réserve Nationale de Camargue" warmly for having welcomed our experiments and contributing to the sampling. We are grateful to the anonymous referees for their detailed and constructive comments, which have contributed to significantly improve this manuscript.

Edited by: H. Wernli

\section{References}

Aemisegger, F., Sturm, P., Graf, P., Sodemann, H., Pfahl, S., Knohl, A., and Wernli, H.: Measuring variations of $\delta^{18} \mathrm{O}$ and $\delta^{2} \mathrm{H}$ in atmospheric water vapour using two commercial laser-based spectrometers: an instrument characterisation study, Atmos. Meas. Tech., 5, 1491-1511, doi:10.5194/amt-5-1491-2012, 2012.

Aemisegger, F., Pfahl, S., Sodemann, H., Lehner, I., Seneviratne, S. I., and Wernli, H.: Deuterium excess as a proxy for continental moisture recycling and plant transpiration, Atmos. Chem. Phys., 14, 4029-4054, doi:10.5194/acp-14-4029-2014, 2014.

Angert, A., Lee, J.-E., and Yakir, D.: Seasonal variations in the isotopic composition of near-surface water vapour in the eastern Mediterranean, Tellus B, 60, 674-684, doi:10.1111/j.16000889.2008.00357.x, 2008.

Armengaud, A., Koster, R. D., Jouzel, J., and Ciais, P.: Deuterium excess in Greenland snow: Analysis with simple and complex models, J. Geophys. Res., 103, 8947-8953, 1998.

Bailey, A., Toohey, D., and Noone, D.: Characterizing moisture exchange between the Hawaiian convective boundary layer and free troposphere using stable isotopes in water, J. Geophys. Res.Atmos., 118, 8208-8221, doi:10.1002/jgrd.50639, 2013.

Bastrikov, V., Steen-Larsen, H. C., Masson-Delmotte, V., Gribanov, K., Cattani, O., Jouzel, J., and Zakharov, V.: Continuous measurements of atmospheric water vapour isotopes in western Siberia (Kourovka), Atmos. Meas. Tech., 7, 1763-1776, doi:10.5194/amt-7-1763-2014, 2014.

Berkelhammer, M., Hu, J., Bailey, A., Noone, D. C., Still, C. J., Barnard, H., Gochis, D., Hsiao, G. S., Rahn, T., and Turnipseed, A.: The nocturnal water cycle in an open-canopy forest, J. Geophys. Res.-Atmos., 118, 10225-10242, doi:10.1002/jgrd.50701, 2013.
Boucher, O., Myhre, G., and Myhre, A.: Direct human influence of irrigation on atmospheric water vapour and climate, Clim. Dynam., 22, 597-603, doi:10.1007/s00382-004-0402-4, 2004.

Brubaker, K. L., Entekhabi, D., and Eagleson, P. S.: Estimation of Continental Precipitation Recycling, J. Climate, 6, 1077-1089, 1993.

Brutsaert, W.: Indications of increasing land surface evaporation during the second half of the 20th century, Geophys. Res. Lett., 33, L20403, doi:10.1029/2006GL027532, 2006.

Celle, H., Daniel, M., Mudry, J., and Blavoux, B: Signal pluie et traçage par les isotopes stables en Méditerranée occidentale. Exemple de la région avignonnaise (Sud-Est de la France), C. R. Acad. Sci. Paris, Earth Planet. Sci., 331, 647-650, 2000.

Celle-Jeanton, H., Travi, Y., and Blavoux, B.: Isotopic typology of the precipitation in the Western Mediterranean region at three different time scales, Geophys. Res. Lett., 28, 1215-1218, 2001.

Craig, H. and Gordon, L. I.: Deuterium and oxygen 18 variations in the ocean and the marine atmosphere, in: Stable Isotopes in Oceanographic Studies and Paleotemperatures, edited by: Tongiorgi, E., p. 9-130, Spoleto, Italy, 1965.

Dai, A., Qian, T., Trenberth, K. E., and Milliman, J. D.: Changes in Continental Freshwater Discharge from 1948 to 2004, J. Climate, 22, 2773-2792, doi:10.1175/2008JCLI2592.1, 2009.

Dansgaard, W.: Stable isotopes in precipitation, Tellus, 16, 436468, 1964.

Destouni, G., Asokan, S. M., and Jarsjö, J.: Inland hydro-climatic interaction: Effects of human water use on regional climate, Geophys. Res. Lett., 37, L184402, doi:10.1029/2010GL044153, 2010.

Eltahir, E. A. B. and Bras, R. L.: Precipitation recycling, Rev. Geophys., 34, 367-378, 1996.

Farlin, J., Lai, C.-T., and Yoshimura, K.: Influence of synoptic weather events on the isotopic composition of atmospheric moisture in a coastal city of the western United States, Water Resour. Res., 49, 3685-3696, doi:10.1002/wrcr.20305, 2013.

Fu, G., Charles, S. P., and Yu, J.: A critical overview of pan evaporation trends over the last 50 years, Clim. Change, 97, 193-214, doi:10.1007/s10584-009-9579-1, 2009.

Galewsky, J., Rella, C., Sharp, Z., Samuels, K., and Ward, D.: Surface measurements of upper tropospheric water vapor isotopic composition on the Chajnantor Plateau, Chile, Geophys. Res. Lett., 38, L17803, doi:10.1029/2011GL048557, 2011.

Gat, J. R.: Oxygen and hydrogen isotopes in the hydrologic cycle, Annu. Rev. Earth Planet. Sci., 24, 225-262, 1996.

Gat, J. R.: Atmospheric water balance - the isotopic perspective, Hydrol. Processes, 14, 1357-1369, 2000.

Gat, J. R. and Matsui, E.: Atmospheric water balance in the Amazon basin: an isotopic evapotranspiration model, J. Geophys. Res., 96, 13179-13188, 1991.

Gat, J. R., Bowser, C. J., and Kendall, C.: The contribution of evaporation from the Great Lakes to the continental atmsophere: estimate based on stable isotope data, Geophys. Res. Lett., 21, 557560, 1994.

Gat, J. R., Shemesh, A., Tziperman, E., Hecht, A., Georgopoulos, D., and Basturk, O.: The stable isotope composition of waters of the eastern Mediterranean Sea, J. Geophys. Res., 101, 64416451, 1996.

Gibson, J. J., Birks, S. J., and Edwards, T. W. D.: Global prediction of $\delta \mathrm{A}$ and $\delta 2 \mathrm{H}-\delta 18 \mathrm{O}$ evaporation slopes for lakes and 
soil water accounting for seasonality, Tellus, 16, 436-468, doi:10.1111/j.2153-3490.1964.tb00181.x, 2008.

Gonfiantini, R.: Environmental isotopes in lake studies, in: Handbook of Environmental Isotope geochemistry, 2, edited by: Fritz, P. and Fontes, J. C., Elsevier, Amsterdam, 113-163, 1986.

Griffis, T. J.: Tracing the flow of carbon dioxide and water vapor between the biosphere and atmosphere: A review of optical isotope techniques and their application, Agric. For. Meteorol., 174-175, 85-109, doi:10.1016/j.agrformet.2013.02.009, 2013.

Griffis, T. J., Lee, X., Baker, J. M., Billmark, K., Schultz, N., Erickson, M., Zhang, X., Fassbinder, J., Xiao, W., and Hu, N.: Oxygen isotope composition of evapotranspiration and its relation to $\mathrm{C} 4$ photosynthetic discrimination, J. Geophys. Res., 116, G01035, doi:10.1029/2010JG001514, 2011.

Gupta, P., Noone, D., Galewsky, J., Sweeney, C., and Vaughn, B. H.: Demonstration of high-precision continuous measurements of water vapor isotopologues in laboratory and remote field deployments using wavelength-scanned cavity ring-down spectroscopy (WS-CRDS) technology, Rapid Commun. Mass Spectrom., 23, 2534-2542, doi:10.1002/rcm.4100, 2009.

$\mathrm{He}, \mathrm{H}$. and Smith, R. B.: Stable isotope composition of water vapor in the atmospheric boundary layer above the forests of New England, J. Geophys. Res., 104, 11657-11673, 1999.

IAEA: Reference Sheet for International Measurement Standards, 5 p., issued 5 May 2009, available at: https://nucleus.iaea.org/rpst/ documents/vsmow2_slap2.pdf (last access: 10 September 2015), 2009.

Iannone, R. Q., Romanini, D., Cattani, O., Meijer, H. A. J., and Kerstel, E. R. Th.: Water isotope ratio $\left(\delta^{2} \mathrm{H}\right.$ and $\left.\delta^{18} \mathrm{O}\right)$ measurements in atmospheric moisture using an optical feedback cavity enhanced absorption laser spectrometer, J. Geophys. Res., 115, D10111, doi:10.1029/2009JD012895, 2010.

Jacob, H. and Sonntag, C.: An 8-year record of the seasonal variation of ${ }^{2} \mathrm{H}$ and ${ }^{18} \mathrm{O}$ in atmospheric water vapour and precipitation at Heidelberg, Germany, Tellus B, 43, 291-300, 1991.

Johnson, L. R., Sharp, Z. D., Galewsky, J., Strong, M., Van Pelt, A. D., Dong, F., and Noone, D.: Hydrogen isotope correction for laser instrument measurement bias at low water vapor concentration using conventional isotope analyses: application to measurements from Mauna Loa Observatory, Hawaii, Rapid Commun. Mass Spectrom., 25, 608-616, doi:10.1002/rcm.4894, 2011.

Jouzel, J., Alley, R. B., Cuffey, K. M., Dansgaard, W., Grootes, P., Hoffmann, G., Johnsen, S. J., Koster, R. D., Peel, D., Shuman, C. A., Stievenard, M., Stuiver, M., and White, J.: Validity of the temperature reconstruction from water isotopes in ice cores, J. Geophys. Res., 102, 26471-26487, 1997.

Jouzel, J., Delaygue, G., Landais, A., Masson-Delmotte, V., Risi, C., and Vimeux, F.: Water isotopes as tools to document oceanic sources of precipitation, Water Resour. Res., 49, 7469-7486, doi:10.1002/2013WR013508, 2013.

Jung, M., Reichstein, M., Ciais, P., Seneviratne, S. I., Sheffield, J., Goulden, M. L., Bonan, G., Cescatti, A., Chen, J., de Jeu, R., Dolman, A. J., Eugster, W., Gerten, D., Gianelle, D., Gobron, N., Heinke, J., Kimball, J., Law, B. E., Montagnani, L., Mu, Q., Mueller, B., Oleson, K., Papale, D., Richardson, A. D., Roupsard, O., Running, S., Tomelleri, E., Viovy, N., Weber, U., Williams, C., Wood, E., Zaehle, S., and Zhang, K.: Recent decline in the global land evapotranspira- tion trend due to limited moisture supply, Nature, 467, 951-954, doi:10.1038/nature09396, 2010.

Keeling, C. D.: The concentration and isotopic abundances of atmospheric carbon dioxide in rural areas, Geochim. Cosmochim. Acta, 13, 322-334, 1958.

Kerstel, E. and Gianfrani, L.: Advances in laser-based isotope ratio measurements: selected applications, Appl. Phys. B-Lasers O., 92, 439-449, 2008.

Kurita, N., Newman, B. D., Araguas-Araguas, L. J., and Aggarwal, P.: Evaluation of continuous water vapor $\delta \mathrm{D}$ and $\delta^{18} \mathrm{O}$ measurements by off-axis integrated cavity output spectroscopy, Atmos. Meas. Tech., 5, 2069-2080, doi:10.5194/amt-5-2069-2012, 2012.

Lai, C.-T. and Ehleringer, J. R.: Deuterium excess reveals diurnal sources of water vapor in forest air, Oecologia, 165, 213-223, doi:10.1007/s00442-010-1721-2, 2011.

Lai, C.-T., Ehleringer, J. R., Bond, B. J., and Paw U, K. T.: Contributions of evaporation, isotopic non-steady state transpiration and atmospheric mixing on the $\delta 180$ of water vapour in Pacific Northwest coniferous forests, Plant, Cell Environ., 29, 77-94, 2006.

Lee, X., Smith, R., and Williams, J.: Water vapour ${ }^{18} \mathrm{O} /{ }^{16} \mathrm{O}$ isotope ratio in surface air in New England, USA, Tellus B, 58, 293-304, doi:10.1111/j.1600-0889.2006.00191.x, 2006.

Lee, X., Huang, J., and Patton, E. G.: A Large-Eddy Simulation Study of Water Vapour and Carbon Dioxide Isotopes in the Atmospheric Boundary Layer, Bound.-Lay. Meteorol., 145, 229248, doi:10.1007/s10546-011-9631-3, 2012.

Medeiros, B., Hall, A., and Stevens, B.: What Controls the Mean Depth of the PBL?, J. Climate, 18, 3157-3172, 2005.

Merlivat, L. and Jouzel, J.: Global Climatic Interpretation of the Deuterium-Oxygen 18 Relationship for Precipitation, J. Geophys. Res., 84, 5029-5033, 1979.

Monteith, J. L.: Evaporation and environment, Symposia of the Society for Experimental Biology, 19, 205-224, 1965.

Noone, D.: Pairing Measurements of the Water Vapor Isotope Ratio with Humidity to Deduce Atmospheric Moistening and Dehydration in the Tropical Midtroposphere, J. Climate, 25, 4476-4494, doi:10.1175/JCLI-D-11-00582.1, 2012.

Noone, D., Galewsky, J., Sharp, Z. D., Worden, J., Barnes, J., Baer, D., Bailey, A., Brown, D. P., Christensen, L., Crosson, E., Dong, F., Hurley, J. V., Johnson, L. R., Strong, M., Toohey, D., Van Pelt, A., and Wright, J. S.: Properties of air mass mixing and humidity in the subtropics from measurements of the $\mathrm{D} / \mathrm{H}$ isotope ratio of water vapor at the Mauna Loa Observatory, J. Geophys. Res., 116, D22113, doi:10.1029/2011JD015773, 2011.

Noone, D., Risi, C., Bailey, A., Berkelhammer, M., Brown, D. P., Buenning, N., Gregory, S., Nusbaumer, J., Schneider, D., Sykes, J., Vanderwende, B., Wong, J., Meillier, Y., and Wolfe, D.: Determining water sources in the boundary layer from tall tower profiles of water vapor and surface water isotope ratios after a snowstorm in Colorado, Atmos. Chem. Phys., 13, 1607-1623, doi:10.5194/acp-13-1607-2013, 2013.

Ohmura, A. and Wild, M.: Is the Hydrological Cycle Accelerating?, Science, 298, 1345-1346, doi:10.1126/science.1078972, 2002.

Pfahl, S. and Wernli, H.: Air parcel trajectory analysis of stable isotopes in water vapor in the eastern Mediterranean, J. Geophys. Res., 113, D20104, doi:10.1029/2008JD009839, 2008. 
Risi, C., Noone, D., Worden, J., Frankenberg, C., Stiller, G., Kiefer, M., Funke, B., Walker, K., Bernath, P., Schneider, M., Wunch, D., Sherlock, V., Deutscher, N., Griffith, D., Wennberg, P. O., Strong, K., Smale, D., Mahieu, E., Barthlott, S., Hase, F., García, O., Notholt, J., Warneke, T., Toon, G., Sayres, D., Bony, S., Lee, J., Brown, D., Uemura, R., and Sturm, C.: Processevaluation of tropospheric humidity simulated by general circulation models using water vapor isotopologues: 1. Comparison between models and observations, J. Geophys. Res., 117, D05303, doi:10.1029/2011JD016621, 2012.

Risi, C., Noone, D., Frankenberg, C., and Worden, J.: Role of continental recycling in intraseasonal variations of continental moisture as deduced from model simulations and water vapor isotopic measurements, Water Resour. Res., 49, 4136-4156, doi:10.1002/wrcr.20312, 2013.

Roderick, M. L. and Farquhar, G. D.: The Cause of Decreased Pan Evaporation over the Past 50 Years, Science, 298, 1410-1411, doi:10.1126/science.1075390, 2002.

Roderick, M. L., Rotstayn, L. D., Farquhar, G. D., and Hobbins, M. T.: On the attribution of changing pan evaporation, Geophys. Res. Lett., 34, L17403, doi:10.1029/2007GL031166, 2007.

Salati, E., Dall'Olio, A., Matsui, E., and Gat, J. R.: Recycling of water in the Amazon Basin: An isotopic study, Water Resour. Res., 15, 1250-1258, 1979.

Schmidt, M., Maseyk, K., Lett, C., Biron, P., Richard, P., Bariac, T., and Seibt, U.: Concentration effects on laser-based $\delta^{18} \mathrm{O}$ and $\delta^{2} \mathrm{H}$ measurements and implications for the calibration of vapour measurements with liquid standards, Rapid Commun. Mass Spectrom., 24, 3553-3561, doi:10.1002/rcm.4813, 2010.

Steen-Larsen, H. C., Johnsen, S. J., Masson-Delmotte, V., Stenni, B., Risi, C., Sodemann, H., Balslev-Clausen, D., Blunier, T., Dahl-Jensen, D., Ellehøj, M. D., Falourd, S., Grindsted, A., Gkinis, V., Jouzel, J., Popp, T., Sheldon, S., Simonsen, S. B., Sjolte, J., Steffensen, J. P., Sperlich, P., Sveinbjörnsdóttir, A. E., Vinther, B. M., and White, J. W. C.: Continuous monitoring of summer surface water vapor isotopic composition above the Greenland Ice Sheet, Atmos. Chem. Phys., 13, 4815-4828, doi:10.5194/acp-13-4815-2013, 2013.

Steen-Larsen, H. C., Sveinbjörnsdottir, A. E., Peters, A. J., MassonDelmotte, V., Guishard, M. P., Hsiao, G., Jouzel, J., Noone, D., Warren, J. K., and White, J. W. C.: Climatic controls on water vapor deuterium excess in the marine boundary layer of the North Atlantic based on 500 days of in situ, continuous measurements, Atmos. Chem. Phys., 14, 7741-7756, doi:10.5194/acp-14-77412014, 2014.

Sturm, K., Hoffmann, G., Langmann, B., and Stichler, W.: Simulation of $\delta^{18} \mathrm{O}$ in precipitation by the regional circulation model REMOiso, Hydrol. Processes, 19, 3425-3444, doi:10.1002/hyp.5979, 2005.

Sturm, P. and Knohl, A.: Water vapor $\delta^{2} \mathrm{H}$ and $\delta^{18} \mathrm{O}$ measurements using off-axis integrated cavity output spectroscopy, Atmos. Meas. Tech., 3, 67-77, doi:10.5194/amt-3-67-2010, 2010.

Sun, S., Meng, P., Zhang, J., Wan, X., Zheng, N., and He, C.: Partitioning oak woodland evapotranspiration in the rocky mountainous area of North China was disturbed by foreign vapor, as estimated based on non-steady-state ${ }^{18} \mathrm{O}$ isotopic composition, Agric. For. Meteorol., 184, 36-47, doi:10.1016/j.agrformet.2013.08.006, 2014.
Sunmonu, N., Muramoto, K., Kurita, N., Yoshimura, K., and Fujiyoshi, Y:: Characteristics of Seasonal Variation of NearSurface Water Vapor D/H Isotope Ratio Revealed by Continuous in situ Measurement in Sapporo, Japan, SOLA, 8, 5-8, doi:10.2151/sola.2012-002, 2012.

Tremoy, G., Vimeux, F., Cattani, O., Mayaki, S., Souley, I., and Favreau, G.: Measurements of water vapor isotope ratios with wavelength-scanned cavity ring-down spectroscopy technology: new insights and important caveats for deuterium excess measurements in tropical areas in comparison with isotope-ratio mass spectrometry, Rapid Commun. Mass Spectrom., 25, 3469-3480, doi:10.1002/rcm.5252, 2011.

Tremoy, G., Vimeux, F., Mayaki, S., Souley, I., Cattani, O., Risi, C., Favreau, G., and Oi, M.: A 1-year long $\delta^{18} \mathrm{O}$ record of water vapor in Niamey (Niger) reveals insightful atmospheric processes at different timescales, Geophys. Res. Lett., 39, L08805, doi:10.1029/2012GL051298, 2012.

Tuinenburg, O. A., Hutjes, R. W. A., and Kabat, P.: The fate of evaporated water from the Ganges basin, J. Geophys. Res., 117, D01107, doi:10.1029/2011JD016221, 2012.

Uemura, R., Matsui, Y., Yoshimura, K., Motoyama, H., and Yoshida, N.: Evidence of deuterium excess in water vapor as an indicator of ocean surface conditions, J. Geophys. Res., 113, D19114, doi:10.1029/2008JD010209, 2008.

Vallet-Coulomb, C., Gasse, F., and Sonzogni, C.: Seasonal evolution of the isotopic composition of atmospheric water vapour above a tropical lake?: Deuterium excess and implication for water recycling, Geochim. Cosmochim. Acta, 72, 4661-4674, doi:10.1016/j.gca.2008.06.025, 2008.

Van der Ent, R. J., Savenije, H. H. G., Schaefli, B., and Steele-Dunne, S. C.: Origin and fate of atmospheric moisture over continents, Water Resour. Res., 46, W09525, doi:10.1029/2010WR009127, 2010.

Wang, L., Caylor, K. K., Villegas, J. C., Barron-Gafford, G. A., Breshears, D. D., and Huxman, T. E.: Partitioning evapotranspiration across gradients of woody plant cover: Assessment of a stable isotope technique, Geophys. Res. Lett., 37, L09401, doi:10.1029/2010GL043228, 2010.

Wang, L., Niu, S., Good, S. P., Soderberg, K., McCabe, M. F., Sherry, R. A., Luo, Y., Zhou, X., Xia, J., and Caylor, K. K.: The effect of warming on grassland evapotranspiration partitioning using laser-based isotope monitoring techniques, Geochim. Cosmochim. Acta, 111, 28-38, doi:10.1016/j.gca.2012.12.047, 2013.

Wassenaar, L. I., Ahmad, M., Aggarwal, P., van Duren, M., Pöltenstein, L., Araguas, L., and Kurttas, T.: Worldwide proficiency test for routine analysis of $\delta^{2} \mathrm{H}$ and $\delta^{18} \mathrm{O}$ in water by isotope-ratio mass spectrometry and laser absorption spectroscopy., Rapid Commun. Mass Spectrom., 26, 1641-1648, doi:10.1002/rcm.6270, 2012.

Welp, L. R., Lee, X., Griffis, T. J., Wen, X.-F., Xiao, W., Li, S., Sun, X., Hu, Z., Val Martin, M., and Huang, J.: A metaanalysis of water vapor deuterium-excess in the midlatitude atmospheric surface layer, Global Biogeochem. Cycles, 26, GB3021, doi:10.1029/2011GB004246, 2012.

Wen, X.-F., Zhang, S.-C., Sun, X.-M., Yu, G.-R., and Lee, X.: Water vapor and precipitation isotope ratios in Beijing, China, J. Geophys. Res., 115, D01103, doi:10.1029/2009JD012408, 2010. 
Wen, X.-F., Lee, X., Sun, X.-M., Wang, J.-L., Hu, Z.-M., Li, S.-G., and Yu, G.-R.: Dew water isotopic ratios and their relationships to ecosystem water pools and fluxes in a cropland and a grassland in China, Oecologia, 168, 549-561, doi:10.1007/s00442011-2091-0, 2012.

Werner, M., Langebroek, P. M., Carlsen, T., Herold, M., and Lohmann, G.: Stable water isotopes in the ECHAM5 general circulation model: Toward high-resolution isotope modeling on a global scale, J. Geophys. Res., 116, D15109, doi:10.1029/2011JD015681, 2011.

Williams, D. G., Cable, W., Hultine, K., Hoedjes, J. C. B., Yepez, E. A., Simonneaux, V., Er-Raki, S., Boulet, G., de Bruin, H. A. R., Chehbouni, A., Hartogensis, O. K., and Timouk, F.: Evapotranspiration components determined by stable isotope, sap flow and eddy covariance techniques, Agric. For. Meteorol., 125, 241258, doi:10.1016/j.agrformet.2004.04.008, 2004.

Worden, J., Noone, D., and Bowman, K.: Importance of rain evaporation and continental convection in the tropical water cycle, Nature, 445, 528-532, doi:10.1038/nature05508, 2007.

Yakir, D. and Sternberg, L. da S. L.: The use of stable isotopes to study ecosystem gas exchange, Oecologia, 123, 297-311, 2000.
Yakir, D. and Wang, X.-F.: Fluxes of $\mathrm{CO}_{2}$ and water between terrestrial vegetation and the atmosphere estimated from isotope measurements, Nature, 380, 515-517, 1996.

Yamanaka, T. and Shimizu, R.: Spatial distribution of deuterium in atmospheric water vapor: Diagnosing sources and the mixing of atmospheric moisture, Geochim. Cosmochim. Acta, 71, 31623169, doi:10.1016/j.gca.2007.04.014, 2007.

Yepez, E. A., Williams, D. G., Scott, R. L., and Lin, G.: Partitioning overstory and understory evapotranspiration in a semiarid savanna woodland from the isotopic composition of water vapor, Agric. For. Meteorol., 119, 53-68, doi:10.1016/S01681923(03)00116-3, 2003.

Zhang, S., Wen, X., Wang, J., Yu, G., and Sun, X.: The use of stable isotopes to partition evapotranspiration fluxes into evaporation and transpiration, Acta Ecol. Sin., 30, 201-209, doi:10.1016/j.chnaes.2010.06.003, 2010.

Zhang, S., Sun, X., Wang, J., Yu, G., and Wen, X.: Short-term variations of vapor isotope ratios reveal the influence of atmospheric processes, J. Geogr. Sci., 21, 401-416, doi:10.1007/s11442-0110853-6, 2011. 